\title{
General Public's Knowledge Regarding Basic Life Support: A Pilot Study with a Portuguese Sample
}

\section{Conhecimento do Público Geral em Suporte Básico de Vida: Um Estudo Piloto com uma Amostra Portuguesa}

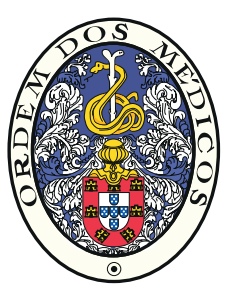

\author{
Carla SÁ-COUTO $\square^{1,2}$, Abel NICOLAU ${ }^{1,2,3}$ \\ Acta Med Port 2019 Feb;32(2):111-118 - https://doi.org/10.20344/amp.10971
}

\begin{abstract}
Introduction: Basic life support is a key manoeuvre in a cardiac arrest situation that can often save a victim's life. This study investigates the general public's knowledge about the fundamentals of basic life support, and its association with previous training/education on basic life support and self-perception of knowledge. A secondary goal is to assess the opinion on training needs.

Material and Methods: This is a cross-sectional, exploratory, and descriptive study, using a convenience sample of 655 individuals. A survey containing 21 questions was applied. A descriptive and inferential statistical analysis explored potential associations between variables.

Results: The mean score for general knowledge $(75.9 \% \pm 14.2 \%)$ was statistically significantly higher $(p<0.001)$ than for technical knowledge $(31.2 \% \pm 29.7)$. Considering the overall knowledge, the mean score was $49.0 \% \pm 20.3 \%$, with $100(15.3 \%)$ respondents scoring equal or higher than $70 \%$, and only $12(1.8 \%)$ answering all questions correctly. Less than $30 \%$ of the sample had previous training in basic life support.

Discussion: The source of knowledge and time elapsed from previous training have relevant and statistically significant associations with the knowledge scores. Association of the self-perception of knowledge and the actual scores showed, in general, that participants have a correct perception of their knowledge. The knowledge scores indicate clear lack of training and knowledge among the general population.

Conclusion: The results of this study reinforce the need for practical and regular basic life support training, ideally early in life and in the workplace. Participants recognize that they have residual or low basic life support knowledge and are motivated to attend training and refresher courses.
\end{abstract}

Keywords: Cardiopulmonary Resuscitation/education; Health Knowledge, Attitudes, Practice; Life Support Systems

\section{RESUMO}

Introdução: O suporte básico de vida é uma manobra fundamental em situação de paragem cardíaca com grande impacto na sobrevida da vítima. Este estudo investiga o conhecimento do público geral sobre os fundamentos do suporte básico de vida e a sua associação com o treino/educação prévia e a autoperceção do conhecimento. Um segundo objetivo é avaliar a opinião sobre as necessidades de treino.

Material e Métodos: Trata-se de um estudo transversal, exploratório e descritivo, utilizando uma amostra de conveniência de 655 indivíduos. A ferramenta de recolha de dados consistiu num questionário contendo 21 questões. Uma análise estatística descritiva e inferencial explorou as possíveis associações entre variáveis.

Resultados: O conhecimento geral teve uma pontuação $(75,9 \% \pm 14,2 \%)$ estatisticamente significativa $(p<0,001)$ superior ao conhecimento técnico $(31,2 \% \pm 29,7)$. Considerando o conhecimento total, a pontuação média foi de $49,0 \% \pm 20,3 \%$, com $100(15,3 \%)$ inquiridos com pontuação igual ou superior a $70 \%$ e apenas $12(1,8 \%)$ respondendo corretamente a todas as questões. Menos de $30 \%$ da amostra teve treino prévio em suporte básico de vida.

Discussão: O conhecimento em suporte básico de vida tem associações importantes e estatisticamente significativas com a proveniência do conhecimento e o tempo decorrido do treino anterior. A associação da autoperceção do conhecimento e as pontuações reais mostraram, em geral, que os participantes têm uma perceção correta do seu conhecimento. As pontuações de conhecimento indicam uma falta de treino e conhecimento na população em geral.

Conclusão: Os resultados deste estudo reforçam a necessidade de treino prático e regular de suporte básico de vida, idealmente no local de trabalho e no início da vida. Os participantes reconhecem que o seu conhecimento em suporte básico de vida é residual ou baixo e estão motivados a participar em cursos de treino e/ou revalidação.

Palavras-chave: Conhecimentos, Atitudes e Prática em Saúde; Reanimação Cardiopulmonar/educação; Sistemas de Suporte de Vida

\section{INTRODUCTION}

One of the leading causes of death in Europe is sudden cardiac arrest, affecting 55 to 113 per 100000 inhabitants per year. ${ }^{1}$

Cardiac arrest is a sudden stop in effective blood circulation due to the heart failing to contract effectively. ${ }^{1,2}$ It is a medical emergency that, in certain situations, is potentially reversible if treated early, otherwise it can lead to death within minutes. ${ }^{1,2}$

The treatment for cardiac arrest is immediate defibrillation if a 'shockable' rhythm is present, while basic life support (BLS) is the key to provide circulatory support and/or to induce a 'shockable' rhythm. ${ }^{1}$ The European Resuscitation Council (ERC) indicates that bystander cardiopulmonary resuscitation (CPR) by lay people increases survival rate by

1. Biomedical Simulation Center. Faculty of Medicine. University of Porto. Porto. Portugal.

2. Center for Health Technology and Services Research (CINTESIS). Faculty of Medicine. University of Porto. Porto. Portugal.

3. Faculty of Engineering. University of Porto. Porto. Portugal.

$\square$ Autor correspondente: Carla Sá Couto. csacouto@med.up.pt

Recebido: 19 de junho de 2018 - Aceite: 03 de setembro de 2018| Copyright @ Ordem dos Médicos 2019 
2 - 4 times, ${ }^{1,3}$ reinforcing the importance of bystander CPR to increase the survival from cardiac arrest. Nevertheless, it is only provided in about $20 \%$ of the out-of-hospital cardiac arrests. ${ }^{1,3}$

In Portugal, according to the National Institute of Medical Emergency (INEM), between 2013 and 2014, there were 23 347 pre-hospital cardiorespiratory arrests. In $15 \%$ of cases, basic life support maneuvers were performed before the arrival of specialized aid ${ }^{4}$. The survival rate in this period was $4.43 \%$, considerably lower compared to other European countries, such as the UK $(8.6 \%)$, the Netherlands $(21 \%)$, or Norway $(25 \%){ }^{4}$

These discrepancies motivated this study, which aims to investigate the general public's knowledge about the fundamentals of BLS, and its association with previous training/ education on BLS and self-perception of knowledge. The associations with the socio-demographic variables such as age, gender, level of education, among others, were also explored. A secondary goal is to assess opinion regarding training needs.

It is expected that the present study will provide relevant data on the Portuguese BLS actual and self-perceived knowledge, and a new highlight on the training needs, encouraging the implementation of efficient training programs.

\section{MATERIAL AND METHODS}

This is a cross-sectional, exploratory, and descriptive study, using a convenience sample. The sample used was selected from the population of the University of Porto, including all staff, students, teachers, and researchers. The inclusion criteria were: to be 18 years or older and to live in Portugal. The exclusion criterion was being a healthcare professional. Non-health care professionals who had previous instruction or training in BLS were considered layperson and included in the study.

The data collection tool was an online structured anonymous questionnaire, comprised of 21 open and multiplechoice questions. Informed consent, explaining the purpose of the study, was included. The questions were adapted from previously published questionnaires ${ }^{5-14}$ and structured in sections: socio-demographic characterization (five questions), BLS general and technical knowledge (nine questions), previous training/experience in BLS (three questions), and opinion regarding the training needs (four questions). Questions concerning knowledge were based on the 2015 and 2017 ERC guidelines for resuscitation,,$^{1,3}$ with special emphasis on chest compressions.

Demographic questions aimed to characterize the study population, including age, gender, degree of education, occupation, and number of children.

The knowledge section refers to the fundamental elements of BLS/CPR and were divided in general (5) and technical (4) knowledge questions. The first was an openended question that assessed the knowledge of the European emergency number (112). The remaining eight questions were multiple-choice questions, in which the partici- pant selected the single correct answer from four options or "Doesn't know". The last option was intended to assess the actual knowledge of the participants, trying to discourage a random selection of answers. For the two categories of knowledge (general/technical) a score was calculated, resulting from the quotient between the number of questions answered correctly and the total number of questions in the category. A total knowledge score was also calculated as a weighted mean of the general $(40 \%)$ and technical $(60 \%)$ knowledge scores, considering that the technical knowledge has higher impact on the victim's outcome.

The following section assessed the source of knowledge, previous participation in BLS formal training, and explored how the participants self-assess their expertise in BLS. These questions provided the study variables, later used in the inferential analysis. The self-assessment question used a linear scale, ranging from 0 to 10 (non-existent skills - 0; expert in BLS - 10). For the sake of interpretation, the original linear scale was stratified into three groups, as follows: Residual (0-2), Low (3-6), and Adequate (7-10).

The last section assesses opinion regarding training needs and includes 4 multiple choice questions related to the availability of BLS training in the professional/academic context, and the desired typology and frequency of training.

The survey was sent by email to the University of Porto population (students, faculty, researchers, administrative employees and other staff), to a total of 40445 people. The questionnaire was accessible for 24 days, between December 14, 2017 and January 6, 2018.

\section{Statistical analysis}

To calculate the minimum sample size, the Portuguese population in 2016 was considered (10 309 573), as well as a confidence level of $95 \%$ for finite populations, and a maximum accepted error of $4 \%$. The estimated minimum sample size was 600 individuals.

A descriptive and exploratory analysis was performed using absolute frequencies $(n)$, relative frequencies (\%), central tendency measurements (mean) and of variance (standard deviation). To facilitate analysis and interpretation of the results, the sample was stratified according to age ([18; 24], [25; 45], and $\geq 45$ years), gender (male and female), degree of education (up to high school, BSc degree, Master or $\mathrm{PhD}$ degree), and occupation (student, teacher/ researcher, staff).

The inferential analysis explored the association between the socio-demographic variables and the selected study variables, with the general and technical knowledge scores. Non-parametric tests were used due to non-normality distribution of the sample. The tests used were KruskalWallis and U-Mann Whitney for independent groups, and Wilcoxon Sign Rank for paired-groups, considering a significance level of $5 \%$. Due to the multiplicity of tests, a Bonferroni correction was applied.

Statistical analysis was conducted using the IBM SPSS Statistics ${ }^{\circledR}$ software, version 24 . 


\section{RESULTS}

A total of 663 volunteer responses were validated, corresponding to a response rate of $1.6 \%$. From the validated responses, 8 were removed by application of the inclusion/ exclusion criteria, resulting in a sample of 655 respondents.

\section{Socio-demographic characterization}

The mean age of the participants was $30.4 \pm 12.8$. The age stratification groups presented 333 participants $(50.8 \%)$ between 18 and 25 years and the distribution according to gender showed that $470(71.8 \%)$ of the respondents were female. The stratification related to the occupation showed that $379(57.9 \%)$ were students (regardless of the level). More than three-quarters of the sample $(75.9 \%, n=497)$ reported to have no children.

Table 1 summarizes the socio-demographic characterization of the sample.

\section{BLS knowledge}

Table 2 presents the results concerning the participants' BLS knowledge grouped in two categories: general knowledge and technical knowledge. The mean score for general knowledge $(75.9 \% \pm 14.2 \%)$ was statistically significantly higher $(p<0.001)$ than for technical knowledge $(31.2 \% \pm$ 29.7). Considering the overall knowledge, the mean score was $49.0 \% \pm 20.3 \%$, with $100(15.3 \%)$ respondents scoring equal or higher than $70 \%$, and only $12(1.8 \%)$ answering all questions correctly.

Nearly $95 \%$ of the respondents know what the European emergency number is and the meaning of the acronym BLS. Regarding the when, where and whom should apply BLS, most respondents correctly indicated that BLS maneuvers should be applied immediately (94.2\%) and in any place and circumstance if safety conditions are guaranteed $(90.2 \%)$, but only $5.5 \%$ indicated that anyone, regardless of

Table 1 - Socio-demographic characterization. Data presented as number of answers $(n=655)$ and percentage.

\begin{tabular}{|c|c|c|}
\hline \multicolumn{3}{|l|}{ Gender } \\
\hline Male & \multicolumn{2}{|c|}{ Female } \\
\hline $185(28.2 \%)$ & \multicolumn{2}{|c|}{$470(71.8 \%)$} \\
\hline \multicolumn{3}{|l|}{ Age } \\
\hline $18 \leq$ years $<25$ & $25 \leq$ years $<45$ & $\geq 45$ years \\
\hline $333(50.8 \%)$ & $221(33.7 \%)$ & $101(15.4 \%)$ \\
\hline \multicolumn{3}{|l|}{ Degree of education } \\
\hline Up to high school & $\mathrm{BSc}$ & MSc or PhD \\
\hline $233(35.6 \%)$ & $214(32.7 \%)$ & $208(31.8 \%)$ \\
\hline \multicolumn{3}{|l|}{ Occupation } \\
\hline Student* & Faculty** & Staff*** \\
\hline $379(57.9 \%)$ & $131(20.0 \%)$ & $145(22.1 \%)$ \\
\hline \multicolumn{3}{|l|}{ Children } \\
\hline Yes & \multicolumn{2}{|l|}{ No } \\
\hline $157(24.1 \%)$ & \multicolumn{2}{|c|}{$497(75.9 \%)$} \\
\hline
\end{tabular}

*: including under and post-graduate students; ${ }^{* *}$ : teachers and/or researchers; ${ }^{* * *}$ : administrative, technical, maintenance or other staff their knowledge, should perform BLS. It is worth mentioning that $83.5 \%$ replied that any knowledgeable individual should apply the maneuvers.

As for the technical questions, a considerable number of participants chose an incorrect answer or "Doesn't know". The question with the highest correct response rate concerned hand positioning, where $55.4 \%$ selected "Center of the chest". The question with the lowest correct response rate concerned the depth of chest compressions, where only 88 respondents (13.4\%) indicated the " $5-6 \mathrm{~cm}$ " option. In this question, almost half of the respondents selected "Doesn't know" (49.0\%). Regarding frequency and the compressions-ventilations ratio, only $20.9 \%$ and $34.8 \%$, respectively, selected the correct answer.

\section{BLS previous training/education and self-assessment of knowledge}

Three hundred and two participants (46.4\%) indicated that their source of knowledge about BLS was through informal means, such as brochures, television or the internet, while 287 participants $(44.1 \%)$ indicated that they had previously participated in specific workshops or formal training. Twenty-five participants $(3.8 \%)$ stated that they have no knowledge in BLS.

Concerning the time elapsed from previous training, $15.4 \%$ attended a training session less than a year ago, but more than half of the participants (50.1\%) never attended a basic life support training session.

As for the self-assessment of knowledge, the large majority of participants $(79.7 \%)$ acknowledged to have residual or low BLS knowledge, with only $20.3 \%$ of the individuals reporting adequate knowledge, Table 3 .

\section{Opinion regarding training needs}

Nearly all participants $(98.3 \%)$ consider that BLS training should be included in their academic or professional context and that the training should be mostly practical although including a theoretical part (95.1\%). Most of the respondents $(76.3 \%)$ consider that the training should be compulsory for all, with refreshment courses annually $(24.7 \%)$ or biannually (33.0\%), Table 4.

\section{General and technical knowledge scores association with other variables}

Inter and intra-groups differences were tested for the all demographic variables and the three study variables (Table 5).

The intra-group differences showed statistically significant differences $(p<0.001)$ between the general and the technical scores, for all sub-groups, with consistently higher scores on general knowledge.

The inter-group analysis presented no statistical differences for all demographic variables subgroups, except for the variable occupation for the technical scores. Contrary to that, the study variables were all significantly different $(p<$ 0.001 ) for all subgroups. Participants who have previously received BLS training (workshops or courses) scored significantly higher for both general $(80.4 \% \pm 9.0 \%$ vs $72.5 \%$ 
Table 2 - BLS general and technical knowledge. Data presented as number of answers $(n=655)$ and percentage, with the exception of general, technical, and overall knowledge scores which are presented as Mean \pm SD. The correct answers are marked in bold.

\section{General knowledge}

$75.9 \% \pm 14.2 \%$

European Emergency Number

112

$620(94.7 \%)$

Wrong Answer

$35(5.3 \%)$

BLS Meaning*

Survival
Basic First Aid
Basic Life Services
Basic Life Support
Doesn't know

$2(0.3 \%)$

$14(2.1 \%)$

$4(0.6 \%)$

$621(94.8 \%)$

$14(2.1 \%)$

Where should BLS be applied?

Only in an emergency medical vehicle

$14(2.1 \%)$

Only indoors

Only in clinical/hospital settings

$1(0.2 \%)$

$13(2.0 \%)$

In any location and circumstance

$591(90.2 \%)$

Doesn't know

$36(5.5 \%)$

When should BLS be applied?

Only when the victim is in an emergency medical vehicle

$7(1.1 \%)$

Only when the victim is indoors

$0(0.0 \%)$

Only when the victim is in a clinical/hospital setting

$2(0.3 \%)$

Immediately, if safety conditions verified

$617(94.2 \%)$

Doesn't know

$29(4.4 \%)$

Who should apply BLS?

Only healthcare professionals

$7(1.1 \%)$

Only healthcare/first aids providers

$49(7.5 \%)$

Anyone who knows BLS

$547(83.5 \%)$

Anyone

$36(5.5 \%)$

Doesn't know

$16(2.4 \%)$

Technical knowledge ${ }^{* *}$

$31.2 \% \pm 29.7 \%$

Hand Placement

\section{Center of the chest}

$363(55.4 \%)$

Right side of the chest

Left side of the chest

$65(9.9 \%)$

Over Xiphoid Appendix

$124(18.9 \%)$

Doesn't know

$101(15.4 \%)$

Compression Frequency (compressions per minute)

$$
\begin{aligned}
& 60-80 \mathrm{cpm} \\
& 80-100 \mathrm{cpm} \\
& 100-120 \mathrm{cpm} \\
& 120-140 \mathrm{cpm} \\
& \text { Doesn't know }
\end{aligned}
$$$$
198(30.2 \%)
$$$$
69(10.5 \%)
$$$$
137(20.9 \%)
$$$$
5(0.8 \%)
$$

Compression Depth (centimeters)

$$
\begin{aligned}
& 2-3 \mathrm{~cm} \\
& 3-4 \mathrm{~cm} \\
& 4-5 \mathrm{~cm} \\
& 5-6 \mathrm{~cm} \\
& \text { Doesn't know }
\end{aligned}
$$$$
85(13.0 \%)
$$$$
86(13.1 \%)
$$$$
75(11.5 \%)
$$

Compression: Insufflation Ratio

$$
321(49.0 \%)
$$

\begin{tabular}{lc}
$15: 1$ & $36(5.5 \%)$ \\
$15: 2$ & $45(6.9 \%)$ \\
$3: 1$ & $77(11.8 \%)$ \\
$\mathbf{3 0}: 2$ & $\mathbf{2 2 8}(\mathbf{3 4 . 8 \% )}$ \\
Doesn't know & $269(41.1 \%)$ \\
\hline
\end{tabular}

*: answers translated from Portuguese. The original options included the initials of the Portuguese acronym (SBV), as follows: SoBreVivência, Socorrismo Básico à Vitima, Serviços Básicos Vitais, and Suporte Básico de Vida; **: all questions referred to the adult, and this information was explicit in the questionnaire; ***: calculated as a weighted mean of the general $(40 \%)$ and technical $(60 \%)$ knowledge scores. 
Table 3 - Previous training/education on BLS and self-assessment of knowledge. Data presented as number of answers and percentage.

\begin{tabular}{cc}
\hline Source of knowledge $(\mathrm{n}=651)$ & \\
\hline Brochure / TV / Internet & $302(46.4 \%)$ \\
Workshop / Formal training & $287(44.1 \%)$ \\
Other & $37(5.7 \%)$ \\
No knowledge & $25(3.8 \%)$ \\
\hline Time elapsed since last training $(\mathrm{n}=655)$ & \\
\hline$\leq 1$ year & $101(15.4 \%)$ \\
$1<$ years $\leq 3$ & $92(14.0 \%)$ \\
$3<$ years $\leq 5$ & $50(7.6 \%)$ \\
$>5$ years & $84(12.8 \%)$ \\
Never & $328(50.1 \%)$ \\
\hline Self-assessment of knowledge $(n=655)$ & \\
\hline 0 - 2 (residual) & $321(49.0 \%)$ \\
3 - 6 (low) & $201(30.7 \%)$ \\
7 - 10 (adequate) & $133(20.3 \%)$ \\
\hline
\end{tabular}

*: to simplify the presentation of results, the original linear scale (0 to 10 , where 0 represents non-existing skills and 10 represents expertise in BLS) was stratified into three groups, as presented.

$\pm 16.2 \%)$ and technical $(47.0 \% \pm 31.4 \%$ vs $18.5 \% \pm 20.9 \%)$ knowledge than those who have other sources of knowledge (TV, internet, brochures, etc.). Similarly, participants who had formal training in the past three years scored significantly higher for both general $(81.4 \% \pm 7.7 \%$ vs $55.7 \%$ $\pm 31.2 \%)$ and technical $(55.7 \% \pm 31.2 \%$ vs $20.9 \% \pm 22.2 \%)$ knowledge than those who had training more than 3 years ago or never had training. Concerning association of the self-perception of knowledge and the actual scores, in general, participants have a correct perception of their (lack of) knowledge, as self-perception scores increased as mean scores for knowledge (general and technical) increased. The positive trend observed between the self-perception scores and the overall knowledge scores is illustrated on Fig. 1, with statistically significant differences between all groups.

\section{DISCUSSION}

Overall, most respondents demonstrated an evident lack of knowledge, with only a small portion (15.3\%) scoring higher than $70 \%$, in the overall knowledge.

General knowledge, assessing the correct emergency number, what is BLS, and where/when/who should apply BLS, had a mean score of $75.9 \%$ indicating that most participants understands the basics of BLS. Of notice, is that, except for "who should apply BLS", more than $90 \%$ of the participants answered all other questions correctly. Nearly $95 \%$ of the participants knew the meaning of BLS and the emergency services number (112), which is in line with the findings of an Australian study, ${ }^{15}$ in which $98 \%$ of 1489 households correctly answered the emergency number. Most participants also knew where and when to apply BLS with correct responses reaching $90.2 \%$ and $94.8 \%$,
Table 4 - Opinion regarding training needs. Data presented as number of answers $(n=655)$ and percentage.

\begin{tabular}{lc}
$\begin{array}{l}\text { BLS training should be available in my professional/academic } \\
\text { context }\end{array}$ \\
\hline Yes & $644(98.3 \%)$ \\
No & $11(1.7 \%)$ \\
\hline BLS training should be mandatory & $500(76.3 \%)$ \\
\hline For everyone & $30(4.6 \%)$ \\
\hline Only for those dealing with risk situations & $114(17.4 \%)$ \\
\hline Optional & $11(1.7 \%)$ \\
\hline No opinion & \\
\hline Typology of training (theoretical and/or practical) & $623(95.1 \%)$ \\
\hline Both, but mainly practical & $16(2.4 \%)$ \\
Both, but mainly theoretical & $16(2.4 \%)$ \\
Only practical & $0(0 \%)$ \\
\hline Only theoretical & \\
\hline Refresher course frequency & $162(24.7 \%)$ \\
\hline Yearly & $216(33.0 \%)$ \\
Every 2 years & $112(17.1 \%)$ \\
Every 3 years & $133(20.3 \%)$ \\
Every 4 or 5 years & $22(3.4 \%)$ \\
Every 10 years & $10(1.5 \%)$ \\
\hline Not needed & \\
\hline
\end{tabular}

respectively. Only $5.5 \%$ of the respondents considered that anyone should apply BLS, while the majority $(83.5 \%)$ considers that it should be anyone who knows BLS. The 2015 guidelines of the ERC ${ }^{1}$ indicates that "untrained lay rescuers should provide compression-only (hands-only) CPR, with or without dispatcher guidance, for adult victims of cardiac arrest. (...) All lay rescuers should, at a minimum, provide chest compressions for victims of cardiac arrest." Considering that $15.4 \%$ of the participants had formal training (workshops/courses) in the last year, this result may suggest that the training contents should be revised or that this concept should be reinforced.

Technical knowledge scores were markedly low for the majority of the sample, revealing a worrying lack of knowledge (and therefore skills) to adequately perform BLS. More than half of the participants $(55.4 \%)$ know how to position hands for chest compressions but only $20.9 \%$ knows the correct frequency and $13.4 \%$ the correct depth. Over $30 \%$ indicated a frequency of "60 - $80 \mathrm{cpm}$ " as the correct frequency, probably misled by the normal adult heart rate. A study on Brazilian layperson SBV knowledge ${ }^{16}$ showed similar results for hand positioning $(51.2 \%)$ and for compression depth $(14.1 \%)$ but considerably lower percentage for the frequency of compressions $(1.3 \%)$. Other studies ${ }^{7,10}$ presented higher rates but referred to healthcare professionals. Nearly $35 \%$ of the participants knew the correct compressions/ventilation ratio. For the technical questions, a relevant number of participants (ranging from $15 \%$ to near $50 \%$, depending on the question) chose the "Doesn't know" 
Table 5 - General and technical knowledge scores (in \%) for sociodemographic variables and for the relevant variables in the study: source of knowledge, previous training, and self-perception of knowledge.

\begin{tabular}{|c|c|c|c|}
\hline & & Knowledge & \\
\hline & General & Technical & $p$ \\
\hline Gender & & & \\
\hline Male $(n=185)$ & $77.4 \pm 11.7$ & $33.0 \pm 30.2$ & $<0.001^{*}$ \\
\hline Female $(n=470)$ & $75.3 \pm 15.0$ & $30.4 \pm 29.6$ & $<0.001^{*}$ \\
\hline$p$ & 0.999 & 0.999 & \\
\hline Age & & & \\
\hline $18 \leq$ years $<25(n=333)$ & $76.2 \pm 12.6$ & $32.4 \pm 29.3$ & $<0.001^{*}$ \\
\hline $25 \leq$ years $<45(n=221)$ & $76.7 \pm 14.5$ & $31.6 \pm 31.0$ & $<0.001^{*}$ \\
\hline$\geq 45$ years $(n=101)$ & $73.3 \pm 18.0$ & $26.0 \pm 28.1$ & $<0.001^{*}$ \\
\hline$p$ & 0.999 & 0.435 & \\
\hline Degree of education & & & \\
\hline Up to high school $(n=233)$ & $75.4 \pm 13.1$ & $34.1 \pm 31.0$ & $<0.001^{*}$ \\
\hline $\operatorname{BSc}(n=214)$ & $76.4 \pm 14.7$ & $32.1 \pm 30.0$ & $<0.001^{*}$ \\
\hline MSc or $\mathrm{PhD}(n=208)$ & $76.0 \pm 14.6$ & $26.8 \pm 27.7$ & $<0.001^{*}$ \\
\hline$p$ & 0.440 & 0.140 & \\
\hline Occupation & & & \\
\hline Student $(n=379)$ & $76.2 \pm 13.1$ & $34.0 \pm 29.7$ & $<0.001^{*}$ \\
\hline Faculty $(n=131)$ & $75.9 \pm 13.3$ & $22.5 \pm 23.2$ & $<0.001^{*}$ \\
\hline Staff $(n=145)$ & $75.2 \pm 17.5$ & $31.4 \pm 33.6$ & $<0.001^{*}$ \\
\hline$p$ & 0.944 & $<0.001^{*}$ & \\
\hline Children & & & \\
\hline Yes $(n=158)$ & $75.1 \pm 16.7$ & $27.7 \pm 30.9$ & $<0.001^{*}$ \\
\hline No $(n=497)$ & $76.1 \pm 13.3$ & $32.2 \pm 29.3$ & $<0.001^{*}$ \\
\hline$p$ & 0.999 & 0.076 & \\
\hline Source of knowledge & & & \\
\hline Workshops or courses $(n=287)$ & $80.4 \pm 9.0$ & $47.0 \pm 31.4$ & $<0.001^{*}$ \\
\hline Others or no knowledge $(n=364)$ & $72.5 \pm 16.2$ & $18.5 \pm 20.9$ & $<0.001^{*}$ \\
\hline$p$ & $<0.001^{*}$ & $<0.001^{*}$ & \\
\hline Previous training & & & \\
\hline$\leq 3$ years $(n=193)$ & $81.4 \pm 7.7$ & $55.7 \pm 31.2$ & $<0.001^{*}$ \\
\hline$>3$ years or never $(n=462)$ & $55.7 \pm 31.2$ & $20.9 \pm 22.2$ & $<0.001^{*}$ \\
\hline$p$ & $<0.001^{*}$ & $<0.001^{*}$ & \\
\hline Self-perception of knowledge & & & \\
\hline $0-2$ (residual) $(n=321)$ & $71.7 \pm 16.5$ & $16.0 \pm 17.7$ & $<0.001^{*}$ \\
\hline $3-6($ low $)(n=201)$ & $78.5 \pm 10.6$ & $34.2 \pm 27.0$ & $<0.001^{*}$ \\
\hline $7-10$ (adequate) $(n=133)$ & $82.1 \pm 8.6$ & $63.2 \pm 30.2$ & $<0.001^{*}$ \\
\hline$p$ & $<0.001^{*}$ & $<0.001^{*}$ & \\
\hline
\end{tabular}

Used tests: Kruskal-Wallis and U-Mann Whitney for independent groups; Wilcoxon Sign Rank for paired-groups; * $p<0.05$, statistically significant; presented $p$-values are adjusted by Bonferroni correction.

option. These results may indicate that the participants were aware of their knowledge and answered truthfully, reassuring that the study results are reliable.

General and technical knowledge associations with the socio-demographic variables showed no statistical differences in all sub-groups, except for occupation regarding technical knowledge. This suggests that, although the study is based on a heterogeneous sample, the answers are not associated with the socio-demographic groups. Surprisingly, participants that are researchers or teachers have lower technical knowledge than students or staff. Moreover, although no statistical differences were found, participants with MSc or PhD also scored lower in terms of technical knowledge than the other participants. Similarly, participants with 45 years or older scored lower, for both general and technical knowledge, than the other age groups. This 


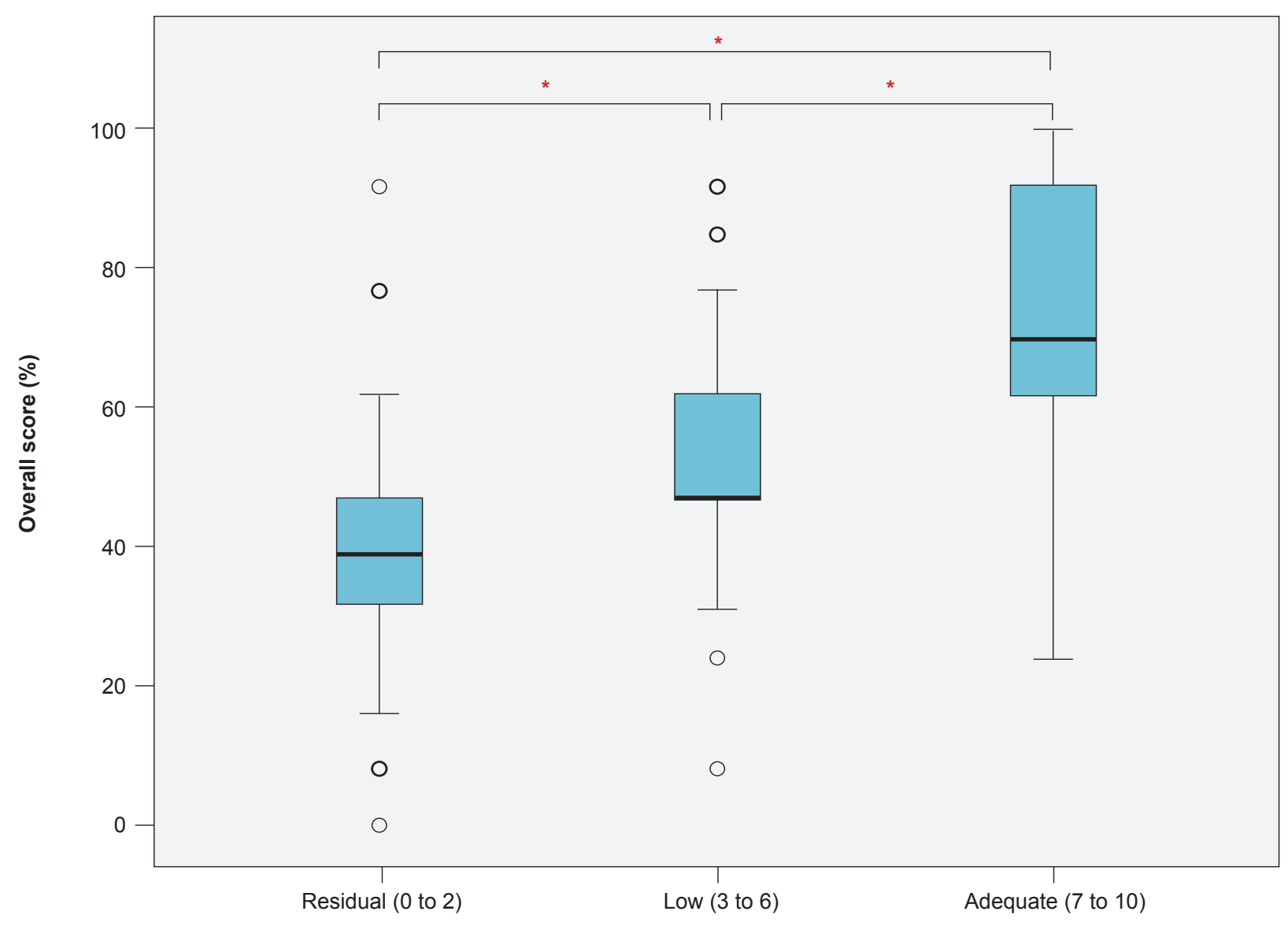

Self-perception of knowledge $(0$ - 10)

Figure 1 - Box-plot of the self-perception of knowledge vs the overall scores.

* indicates statistically significant $(p<0.001)$ for the $U$ Mann-Whitney test.

can be partially explained by the integration of BLS in $3^{\text {rd }}$ cycle of basic education curricula, in Portuguese schools, since $2013,{ }^{17}$ and other sporadic measures (e.g. masstraining) that have been delivered to young generations, increasing BLS awareness and knowledge. Several studies indicate that the training in BLS should begin in the student population and before the start of higher education. $5,11,18,19$

A total of $43.8 \%(n=287)$ of the sample had attended some form of BLS training at some stage in their lifetime. Similar results $(54.1 \%)$ were found in a study from south eastern Michigan (USA, 2006), ${ }^{20}$ but other studies present quite different estimates, ranging from 17.8\% (Portugal, $2015)^{13}$ to $77.9 \%$ (Australia, 2011). ${ }^{21}$

The source of knowledge and time elapsed from previous training have relevant and statistically significant associations with the knowledge scores. Participants who have been in a course/workshop in the last three years $(n=193)$ had mean rates of $81.4 \%, 55.7 \%$, and $66.0 \%$, in the general, technical, and overall scores, respectively. This is a promising result as it confirms that, if formal training is delivered, it increases knowledge. ${ }^{9,18}$ Nevertheless, the technical score indicates that the acquired knowledge is insufficient. Moreover, these participants represent less than $30 \%$ of the sample, demonstrating that there is an evident lack of training and knowledge among the general population.
Participants showed a suitable perception of their knowledge, as self-perception scores increase as mean scores for knowledge (general, technical, and total) increase. Nearly $80 \%$ of the sample considers having residual or low knowledge (self-assessment scores $<7$ ), which was corroborated by the low scores obtained by this group. A positive trend can be observed between the self-perception scores and the overall knowledge scores, with statistically significant differences in all subgroups. These results provide validity to the sample judgement and opinion.

Participants' opinion regarding training needs reinforces the previous results. Nearly all participants $(98.3 \%)$ consider that BLS training should be available in their professional/academic context, and the majority believe that the training should be mandatory $(76.3 \%)$, and mostly practical $(95.1 \%)$, with refreshment sessions between 1 and 5 years later $(95.1 \%)$. In another study ${ }^{13}$ with a Portuguese sample, approximately $95.6 \%$ of the sample showed availability to attend training and $84.9 \%$ indicated that it should be offered in the workplace, which is in-line with the current results. Knowledge update is relevant and considered in the accredited BLS Portuguese courses organized by the Portuguese Red Cross, which have a validity of three years for the European First Aid Course, and five years for the Proximity First Aid Technician. ${ }^{22}$ 


\section{Limitations}

The convenience sample used in this study may not represent the entire Portuguese population, considering that the respondents are directly related to a higher education institution of a metropolitan area. These two factors may lead to a bias in the responses and overestimated scores.

The low response rate $(1.6 \%)$ can also be considered a limitation, although the number of respondents exceeds the calculated sample size. The period of data collection may have influenced the response rate, as it included the Winter break. Considering the voluntary participation in the study, another possible justification could be the reduced familiarity/interest in the topic. The availability of time may also have influenced the response rate, although the participants were informed that it would take less than five minutes.

Another limitation is the use of scores on theoretical knowledge, as it may not reflect the practical skills of the participants.

Although out of the scope of this study, some results were unexpected and could be interesting to explore the reasoning behind specific answers. However, this would increase the length and response time of the survey and potentially decrease the response rate.

\section{CONCLUSION}

The results of this study reinforce the need for practical and regular BLS training, ideally early in life and in the workplace. Participants recognize that they have residual or low BLS knowledge and are motivated to attend training

\section{REFERENCES}

1. Perkins GD, Handley AJ, Koster RW, Castrén M, Smyth MA, Olasveengen T, et al. European Resuscitation Council Guidelines for Resuscitation 2015: Section 2. Adult basic life support and automated external defibrillation. Resuscitation. 2015;95:81-99.

2. Patil KD, Halperin HR, Becker LB. Cardiac arrest: resuscitation and reperfusion. Circ Res. 2015;116:2041-9.

3. Perkins GD, Olasveengen TM, Maconochie I, Soar J, Wyllie J, Greif $\mathrm{R}$, et al. European Resuscitation Council Guidelines for Resuscitation: 2017 update. Resuscitation. 2018,123:43-50.

4. Caldeira PD. A sobrevivência da paragem cardiorespiratória e o investimento em iniciativas de intervenção na população. Oeiras: Universidade Atlântica; 2016.

5. Fernandes JM, Leitel AL, Auto BS, Lima JE, Rivera IR, Mendonça MA. Teaching basic life support to students of public and private high schools. Arq Bras Cardiol. 2014;102:593-601.

6. Jordan T, Bradley P. A survey of basic life support training in various undergraduate health care professions. Resuscitation. 2000;47:321-3.

7. Chandrasekaran S, Kumar S, Bhat SA, Saravanakumar, Shabbir PM, Chandrasekaran VP. Awareness of basic life support among medical, dental, nursing students and doctors. Indian J Anaesth. 2010;54.2:121.

8. Rajapakse R, Noč M, Kersnik J. Public knowledge of cardiopulmonary resuscitation in Republic of SloveniaAllgemeinwissen über kardiopulmonale-Reanimation (CPR) in der Republik Slowenien. Wien Klin Wochenschr. 2010;122:667-72.

9. Shrestha R, Batajoo KH, Piryani RM, Sharma MW. Basic life support: knowledge and attitude of medical/paramedical professionals. World $\mathrm{J}$ Emerg Med. 2012;3:141-5.

10. Baduni N, Prakash P, Srivastava D, Sanwal MK, Singh BP. Awareness of basic life support among dental practitioners. Natl J Maxillofac Surg. 2014;5:19-22.

11. Aaberg AM, Larsen CE, Rasmussen BS, Hansen CM, Larsen JM. Basic life support knowledge, self-reported skills and fears in Danish high school students and effect of a single 45-min training session run by junior doctors; a prospective cohort study. Scand J Trauma Resusc Emerg Med. 2014;22:4. and refreshment courses.

Often algorithms and teaching methods can be complex and unattractive to the population, so it may be wise to use innovative and effective methods for practical learning and retention of knowledge.

\section{ACKNOWLEDGEMENTS}

The authors would like to thank the participants of this study. A special thanks to Pedro Sá-Couto for the relevant discussions on the statistical analysis.

\section{PROTECTION OF HUMANS AND ANIMALS}

The authors declare that the procedures were followed according to the regulations established by the Clinical Research and Ethics Committee and to the Helsinki Declaration of the World Medical Association.

\section{DATA CONFIDENTIALITY}

The authors declare having followed the protocols in use at their working center regarding patients' data publication. Patient consent obtained.

\section{CONFLICTS OF INTEREST}

All authors report no conflict of interest.

\section{FUNDING SOURCES}

This article was supported by National Funds through FCT - Fundação para a Ciência e a Tecnologia within CINTESIS, R\&D Unit (reference UID/IC/4255/2019).

12. Sasaki M, Ishikawa $H$, Kiuchi $T$, Sakamoto $T$, Marukawa S. Factors affecting layperson confidence in performing resuscitation of out-of-hospital cardiac arrest patients in Japan. Acute Med Surg. 2015;2:183-89.

13. Dixe MA, Gomes JC. Knowledge of the Portuguese population on basic life support and availability to attend training. Rev Esc Enferm USP. 2015;49:640-9.

14. Chen M, Wang Y, Li X, Hou L, Wang Y, Liu J, et al. Public knowledge and attitudes towards bystander cardiopulmonary resuscitation in China. Biomed Res Int. 2017;2017:3250485.

15. Smith KL, Cameron PA, McR Meyer AD, McNeil JJ. Is the public equipped to act in out of hospital cardiac emergencies? Emerg Med J. 2003;20:85-7.

16. Neto JA. Basic life support knowledge and interest among laypeople. Int J Cardiovasc Sci. 2016;29:443-52.

17. Branquinho C, Gaspar PJ. Competência em suporte básico da vida nas comunidades escolares: uma perspectiva de cidadania. Leiria: Instituto Politécnico de Leiria; 2017.

18. Tavares A, Pedro N, Urbano J. Ausência de formação em suporte básico de vida pelo cidadão: um problema de saúde pública? Qual a idade certa para iniciar? Rev Port Saúde Pública. 2016;34:101-4.

19. Meissner TM, Kloppe C, Hanefeld C. Basic life support skills of high school students before and after cardiopulmonary resuscitation training: a longitudinal investigation. Scand J Trauma Resusc Emerg Med. 2012,20:31.

20. Swor R, Khan I, Domeier R, Honeycutt L, Chu K, Compton S. CPR training and CPR performance: do CPR-trained bystanders perform CPR? Acad Emerg Med. 2006;13:596-601.

21. Arbon P, Hayes J, Woodman R. First aid and harm minimization for victims of road trauma: a population study. Prehosp Disaster Med. 2011;26:276-82.

22. Cruz Vermelha Portuguesa. Cruz Vermelha Portuguesa - Cursos de Socorrismo. [online]. [accessed 2018 May 14]. Available at: https://www. cruzvermelha.pt/forma\%C3\%A7\%C3\%A3o-ensino/cursos-de-socorrismo.html. 